\title{
In Search of Smart Specialization to Ensure the Sustainable Development of the Post-Conflict Territory: the Case of the Luhansk Region in Ukraine
}

\author{
By Hanna Shevtsova ${ }^{1}$, Nataliia Shvets ${ }^{2}$, Maiia Kramchaninova ${ }^{2}$, \\ Hanna Pchelynska ${ }^{2}$
}

\begin{abstract}
This work highlights a range of problems related to ensuring sustainable development of postconflict territories, as well as ways to overcome those through smart specialization approach. The influence of military conflict on Luhansk region's economy structure and economy's pace of development had been determined. Capacities of smart specialization as a contemporary tool meant for intensifying innovative development, structural modernization and improving competitiveness of regions had been studied. While researching regional context the current state and structure of the chemical sector, which is region's traditional specialty, had been analyzed and also its SWOT analysis had been conducted. Potential for diversification, innovative and cross-sectoral evolution of the existing chemical business was discovered. We pay attention to chemical production's digitalization horizons and its integration into rapidly growing region's agricultural sector as part of precision farming concept. The suggested agrochemical ecosystem's model facilitates communications between leading stakeholders, increases efficiency of entrepreneurial discovery process, creates new areas of specialization and new leverage for ensuring region's sustainable development.
\end{abstract}

Keywords: sustainable development, smart specialization, chemical industry, agriculture, ecosystem, precision farming, Lubansk region

\section{Introduction}

Ukraine has assumed international obligations, aimed at ensuring sustainable development, that are listed in United Nations strategic documents, particularly "The United Nations Millennium Declaration" (2000), "Declaration Transforming our world: the 2030 Agenda for Sustainable Development" (2015). Global Sustainable Development Goals (SDGs) are to be adopted to Ukraine's context and to be taken into account when strategically planning country's development and that of its regions'. (President of Ukraine, 2019). A set of problems specific to Ukraine throughout the years brings out the importance of sustainable development concept. Those are dominations of resourceintensive and energy-intensive sectors and technologies, export orientated on raw materials and excessive concentration of non-diversified technologically outmoded manufactures in the old industrial regions. The country's economy so far demonstrates low efficiency, is environmentally unsafe and incapable of resolving a number of social issues. Lately an objective reason behind deceleration of movement towards sustainable development for Ukraine had been the escalation of military conflict on the East side, which had started in 2014 and still lasts. The range of economic, social and 
environmental problems had drastically widened. Post-conflict regions - Donetsk and Luhansk, having lost a substantial part of population and manufacturing potential, ended up in a particularly difficult situation. The studies had shown that these regions over the pre-conflict period displayed higher indexes in comparison to other regions and Donetsk region was amongst the leaders. After the conflict, Luhansk and Donetsk regions became the only outsiders or followers among the followers with index values lower than the national average (Semenenko, 2019).

Post-conflict regions particularly require external financial and technical assistance at the initial stage of exit from the recession. Nevertheless, such support shouldn't replace the mobilization of region's domestic resources for self-development (Panić, 2009). Postconflict regions should overcome the majority of problems on their own and hold fast to the course of sustainable development. In order to achieve this it's necessary to diversify, structurally modernize the economy, develop innovations through nurturing business environments, improve investment climate, which as a result - gets a higher competitiveness for each region. European countries develop and implement smart specialization strategies for such purposes. (Smart Specialisation Platform, 2016).

D. Foray is one of the developers of smart specialization concept, who sees it as an economic system's (region's, for instance) capacity to generate new specializations through discovering new areas of opportunities and local concentrations, areas-relevant resource and competence agglomeration (Foray, 2015). OECD experts had determined the approach, built on smart specialization concept, as the one combining industrial, educational and innovative policies and offering the countries or regions to define and chose a limited set of priority areas to invest in based on knowledge, with a focus on strengths and comparative advantages (OECD, 2013).

Smart specialization gradually gets an application and a spot in Ukrainian regional policy. Zaporizhia, Odessa, Kharkiv regions for the first time in Ukraine had piloted projects on smart specialization and those regions had been connected to European S3 Platform. In 2018 Ukrainian government had agreed to a widespread use of smart specialization approach for regional development's strategic planning and had added certain points to methodology of drafting of strategic documents.

Smart specialization methodology is being implemented in Ukraine under the guidance and supervision of Joint Research Centre (JRC), which is the European Commission's science and knowledge service. This methodology is new and complex. It is yet at an early stage, forming and developing, undergoing testing at various regions and countries. Smart specialization approach can't be fixed and versatile, because every region has unique resource capacity and environment at the starting point of its implementation.

Ukrainian economy has a potential to develop, however, it's far from being at the European level and is highly unstable. That's why the methodology developed by European Commission should be applied towards Ukrainian environment. This is particularly necessary for post-conflict regions of Ukraine, given that those social and economic system had went through some significant negative change. Pre-conflict and post-conflict statistical data on these regions is incomparable, while the last period encompasses a small time range. These are what limits possibilities to apply a full set of methodological tools for strategic planning, hence the choice of instruments needs clarification in post-conflict case. 
This research is dedicated to implementing ideas and smart specialization principles to regions with a post-conflict environment, as well as searching for promising tools aimed at ensuring region's sustainable development. The object chosen to be researched is Luhansk region.

\section{Luhansk region as a post-conflict territory}

Ukraine is divided into 25 regions (including the temporarily occupied territory of the Autonomous Republic of Crimea) and each one has its own ecosystem with peculiar context, valuable resources and sectorial structure. For a long time Luhansk region was one of the leaders of Ukrainian industry. Mining and manufacturing used to dominate in the region satisfying needs within and outside of it. In 2014 a military conflict broke out in the region and once it de-escalated a great part of industrial assets ended up in occupied territories. Luhansk region's economic potential collapsed (Figure 1).
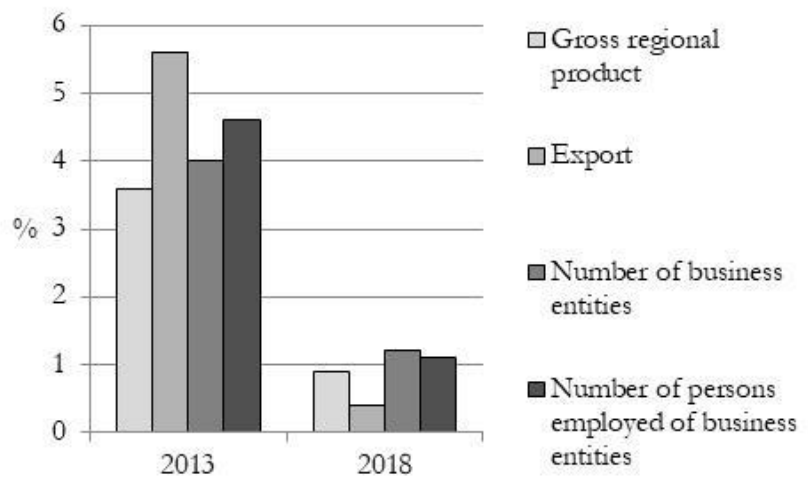

Figure 1. Luhansk region's contribution to Ukrainian rates

Until 2014 all of Luhansk region's economic indicators stood at the average level, but at the moment Luhansk region is amongst Ukraine's most poor regions. In 2015 gross regional product had dropped by 57\% in comparison with 2013 level (pre-conflict period), industrial production index had dropped by 66\%. In 2017 gross added value stood at $55 \%$ of its index in 2013 . The military conflict caused industry and agriculture's roles in compilation of sum of regional added values to reverse. In 2013 the ratio was $34.4 \%$ to $6.9 \%$, in $2017-14.6 \%$ to $21.3 \%$. The structure of regional products sold had made significant movements towards agricultural part's increase and decline in contribution from industry. Meaning, in the past 5 years region's industrial potential had decreased and region is now step by step transforming into agricultural one. This tendency is a dangerous one due to increase in skilled workforce outflow and intensification of social tension in the region. So at this stage it's important to determine the economic sectors that should become the foundation for region's neoindustrial restoration and have capacity to create new leverage for its development. Smart specialization concept can be used exactly for these purposes. 


\section{Identification of smart priorities}

Regional smart specialization's success highly depends on choosing the right sectorial priorities. JRC recommends this choice to be made through analyzing the regional context and potential for innovation, which includes the estimation of economic, scientific and technological specializations of the region. At this stage it's necessary to have a wide range of statistics dating 5-7 years back (Foray, 2012). However, given the situation in Luhansk region to analyze data the period from 2014 to 2017 has been adopted, since earlier periods cover data of those territories that are temporary out of Ukraine's control. Moreover, the analysts have to operate using only a very limited set of indicators, because several recommended indicators are absent in official statistics and getting those requires extra resources that are unavailable. Under such circumstances the results of quantitative analysis can be unreliable. That's the reason why the main findings on regional context and potential for innovation should be concluded, based on research of region's strong suits and possibilities for its economic transformation. Here it's necessary to take into consideration the assumptions on smart specializations: "... concentrating activities on those areas of science, research and innovation that will be adequate for the resources and skills of a region and will contribute to the strengthening of its competitive advantages;..." (Wiatrak, 2018).

Luhansk is a region with a former industrial backbone, so sector-related specifics of the existing clusters, historical regional peculiarities, as well as the features of regional innovative ecosystem are worth taking in account when defining the direction.

One of the important components of regional industrial sector was and still is a chemical industry. We pointed out earlier (Amosha, 2019) that in 2013 region had produced and distributed $6.8 \%$ of Ukrainian chemical output, including $13.7 \%$ of basic chemicals. Its part in Ukrainian export made $12 \%$. Until 2015 Luhansk region was a net exporter, while Ukrainian chemical sector generally demonstrated substantial negative foreign trade balance.

This particular sector used to contain 259 companies $(14 \%$ the total number of industrial entities), including 63 - manufacture of chemicals products, 4 - pharmaceuticals, 102 rubber and plastic, 90 - construction chemistry, employing 20.7 thousand people (9\% of employed in the industry).

Chemical sector had faced serious damage due to a military conflict in the region and due to partial loss of assets remaining on non-government-controlled territories. Nevertheless, the economic potential of this sector is as significant for Luhansk region as it was before.

At the present moment chemical sector contains 94 enterprises $(20 \%$ the total number of industrial entities) employing approximately 8.7 thousand people (27\% of employed in the industry). On controlled territory there is only one pharmaceutical company left. Rubber and plastic (3.4 times less) and construction chemistry (5.2 times less) productions had suffered large cuts. Those sectors are represented mostly by small businesses that are faster to respond to deteriorating conditions, have smaller financial capacities and bear smaller losses upon closure or relocation of business. More than $80 \%$ of regional chemical industry's total output is provided by large and medium-sized basic chemistry enterprises. The major part of this output is nitrogen mineral fertilizers meant 
for agriculture.

In 2013 chemical sector's share in volume of regional manufacturing products sold had been barely exceeding the national rate (Figure 2). In 2017-2018 region's chemical sector had increased its distribution rates and hit 26\% value. Meanwhile, throughout Ukraine its role has barely changed, the index remained $14 \%$.

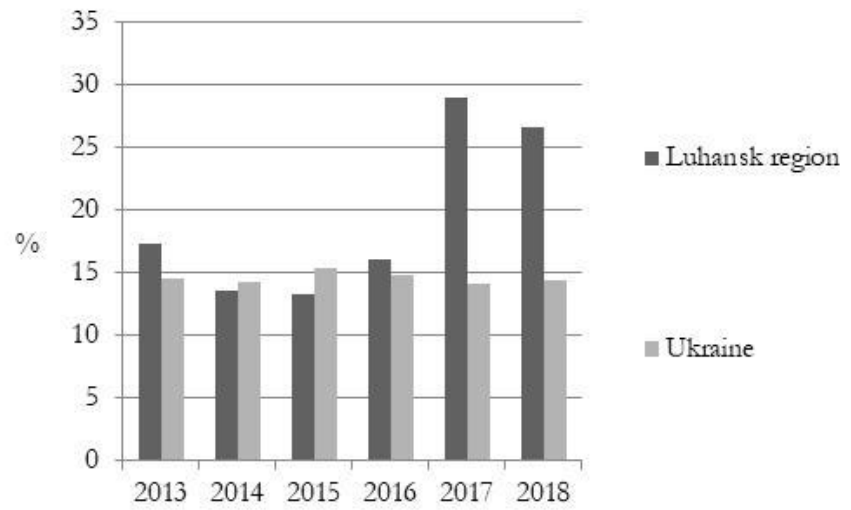

Figure 2. Share of chemical products

Once the conflict started chemical export had drastically decreased (Figure 3), nevertheless its relative contribution to regional foreign exchange earnings had increased significantly.

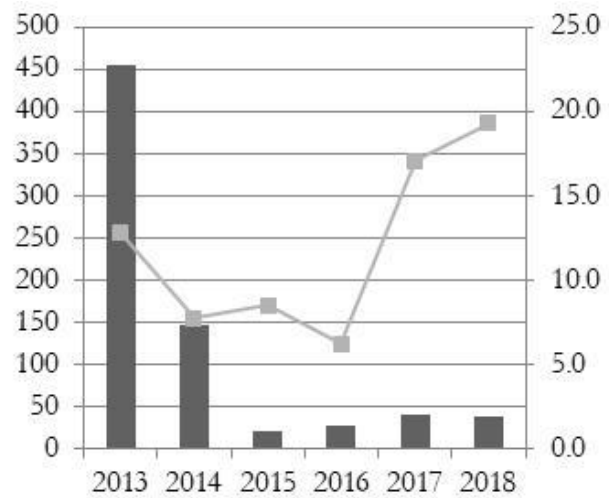

$\mathrm{mln} \$$

5.0

- Share of

chemical

products, $\%$

Figure 3. Chemical export

Clearly, improvement of certain rates occurred while the output of other industries had reduced. However, it's also safe to say that chemical production's influence on regional economics is increasing, and its preserved potential should become the foundation for restoring Luhansk region's industrial sector.

Once hit its minimum in 2015, regional chemical business underwent restructuration and consolidation processes, partially re-gained positions at certain manufacturing segments and lately has been demonstrating signs of stability. However, ensuring further 
sustainable development requires modernization.

It's necessary above all to get away from domination of a single sector - nitrogen related. Chemical industry should diversify, it can and should obtain new innovative tendencies. There is a certain background to achieve this. The SWOT analysis was conducted by the Working Group to describe strategic features of Luhansk region's chemical sector and further identify prospective areas of regional smart specialization.

The authors finalized the results and displayed those in Table 1.

Table 1. Luhansk region's SWOT analysis of chemical complex

\begin{tabular}{|c|c|}
\hline Strengths & Weaknesses \\
\hline $\begin{array}{l}\text { Industry-specific labor potential, as well as } \\
\text { secondary and higher education institutions to } \\
\text { create and develop it. } \\
\text { Concentration of engineering companies and } \\
\text { research institutes. } \\
\text { Small and medium-sized chemical enterprises } \\
\text { active in innovation. } \\
\text { Available industrial spaces and manufacturing } \\
\text { infrastructure placed close to each other which } \\
\text { simplifies value chain's extension. } \\
\text { Large basic chemical enterprises, executing } \\
\text { primal energy-intensive processing of raw } \\
\text { materials and producing intermediate products } \\
\text { for SME. } \\
\text { Sufficient SMEs network having potential for } \\
\text { diversification and extending value chains. } \\
\text { Loyalty from locals to chemical productions. }\end{array}$ & $\begin{array}{l}\text { Outdated technical and technological } \\
\text { capabilities and low level of energy efficiency } \\
\text { rates for baseline production. } \\
\text { Poor level of automatization and digitization. } \\
\text { Poor processing of raw material, short value } \\
\text { chain. } \\
\text { Unreliability of power supply. } \\
\text { Complex logistics, underdeveloped traffic } \\
\text { network. } \\
\text { High dependency on prices of imported } \\
\text { resources. } \\
\text { Low quality of local raw materials. } \\
\text { Outflow of skilled workers and engineers. } \\
\text { Difficulty accessing financial resources and } \\
\text { lack of small and medium-sized enterprises' } \\
\text { institutional support. } \\
\text { Low investment appeal of outdated factories. } \\
\text { Business' poor coherence and low initiative in } \\
\text { search of development areas. }\end{array}$ \\
\hline Opportunities & Threats \\
\hline $\begin{array}{l}\text { Creating institutional conditions for setting off } \\
\text { innovative and investment activities. } \\
\text { Emerging cross-sectoral cooperation and } \\
\text { achieving the positive synergy as a result of } \\
\text { partnership. } \\
\text { Proactivity of international organizations to } \\
\text { support region development. } \\
\text { Extending markets, internal and external, taking } \\
\text { over new market trends. } \\
\text { Creating industrial (chemical) parks as a special } \\
\text { economic zone. } \\
\text { Investment in brownfield sites. }\end{array}$ & $\begin{array}{l}\text { Prolonged political and economic instability. } \\
\text { Escalation of military aggression. } \\
\text { Escalation of underinvestment. } \\
\text { Increasing level of chemical product imports. } \\
\text { Increase in prices of imported raw materials } \\
\text { and intermediate goods. } \\
\text { Decrease in effective demand from end } \\
\text { consumers and intermediate goods' } \\
\text { consumers. } \\
\text { Rising entry barriers on external market, } \\
\text { international competition intensification. } \\
\text { Lack of interest and positive attitude from } \\
\text { private business to cooperate with authorities. }\end{array}$ \\
\hline
\end{tabular}

Region's important feature is large amount of its labor resources being orientated towards chemical sector. Informal chemical cluster has been emerged here a long time ago, existing within Sievierodonetsk - Lysychansk - Rubizhne industrial hub and remained intact on territories controlled by Ukraine. This cluster includes manufacturing 
enterprises of various sizes, servicing, intermediary, logistic companies and complex infrastructure facilities. Here are also located leading chemical research and project organizations, as well as educational institutions, which lay the ground for cluster's scientific and educational potential (Table 2). Thus, Volodymyr Dahl East Ukrainian National University's scientists of Chemical engineering and Environmental science department had registered approximately 100 patents in the past 10 years.

Table 2. Region's leading chemical scientific and exploratory project organizations and universities

\begin{tabular}{|l|l|l|}
\hline $\begin{array}{l}\text { Private JSC } \\
\text { Severodonetsky } \\
\text { ORGHIM }\end{array}$ & $\begin{array}{l}\text { KHIMTEKHNOLOGIYA, } \\
\text { LLC }\end{array}$ & $\begin{array}{l}\text { Volodymyr Dahl East Ukrainian } \\
\text { National University }\end{array}$ \\
\hline $\begin{array}{l}\text { Major lines of } \\
\text { activities } \\
\text { Engineering, geology } \\
\text { and geodesy activities, } \\
\text { rendering relevant } \\
\text { technical consulting } \\
\text { services. } \\
\text { Other line of activity } \\
\text { Professional technical } \\
\text { education. }\end{array}$ & $\begin{array}{l}\text { Major lines of activities } \\
\text { Engineering, geology and } \\
\text { geodesy activities, rendering } \\
\text { relevant technical consulting } \\
\text { services. } \\
\text { Other line of activity } \\
\text { Researches and experimental } \\
\text { developments in the } \\
\text { biotechnology, other natural } \\
\text { and technical sciences field. }\end{array}$ & $\begin{array}{l}\text { Chemical engineering and } \\
\text { Scientific activity } \\
\text { Catalytic and thermal transformation } \\
\text { of chemicals in various state and of } \\
\text { various composition; } \\
\text { Exploring catalyst production and } \\
\text { disposal technology; } \\
\text { Recycling of polymer compounds. } \\
\text { Training professionals } \\
\text { Chemical technologies and } \\
\text { engineering; }\end{array}$ \\
\hline
\end{tabular}

Also, small business has been operating in the region for a long time now, displaying better results than larger chemical enterprises do, whose role in creating regional product had drastically decreased in the past decade. The reasons behind this are loss of competitive advantages by large enterprises due to technological backwardness and failure to implement innovative strategies. These systematic causes add up with the others, which had appeared due to the military conflict. As a result at the present time a big part of manufacturing sites remain unused and are unlikely to be used as intended. One of the possible ways to transform old large plants is their restructure according to brownfield principles and set up of chemical parks. Parks can give real manufacturing, technological, infrastructural support for small and medium businesses to diversify production and extend value chains.

Once political and economic situation will be stabilized, favorable institutional and investment conditions in the region will be established, it will become possible to ensure effective cooperation between production, science and education, as well as to emerge an active innovative environment.

Chemical complex's SWOT analysis shows that Luhansk region has a certain development potential attributed to industrial legacy and sectoral resources. From the smart specialization concept's perspective identifying priorities correctly is important to choose pathway for regional development (Detterbeck, 2017). An important criteria for selecting priorities is a possibility to combine domains for cross-sectoral cooperation in 
order to promote existing regional competitive edges (Foray, 2012).

We believe collaboration between chemical industry and agriculture, as well as establishment of an agrochemical ecosystem are promising areas of regional smart specialization. Now agriculture is region's sector of priority and driving force for economy. This is enshrined in Luhansk Region Development Strategy until 2020 (strategic goal 3 "Economic recovery and shift to sustainable development", operational objective 3.1 "Ensure resilience of regional economics and shift to sustainable growth", task 3.1.3 "Contribute to agricultural productivity and efficiency" and 3.1.4 "Contribute to processing of agricultural products and to expanding markets").

At the moment agricultural sector makes a dominant part of regional added value and comprises a significant part of export. Region has sufficient amount of cultivated lands and agricultural producers. In 2018 this sector concentrates 30\% of regional enterprises, $95 \%$ of which represent small business. However, as a result of unsystematic exploitation and lack of efficient restoring tools region's cultivated lands lately had been hitting low productivity and agricultural sector had been demonstrating low yields in comparison to other regions of Ukraine. This leads to a partial loss of regional potential gross product. Agricultural intensification needs an appropriate balanced agro-technical support that at the same time has to adhere to environmental requirements on fertilizers and other agrochemicals use.

A promising tendency for raising agricultural production's efficiency is implementation of innovative solutions corresponding to SDGs.

The international experience shows the emergence of such solutions to be the result of the activities of various cross-sectoral innovative ecosystems, including cooperation between agricultural sector and chemical production in order to implement precision farming concept.

\section{Implementation of precision farming concept}

Under the influence of global technological trends all fields of human endeavor face drastic changes. Modern challenges (climate change, aggravated environmental hazards, population growth) rise new issues for agricultural sector as well.

Year 2015 further updated SDGs up to year 2030. Another goal has been identified: "end hunger, achieve food security and improved nutrition and promote sustainable agriculture". The "sustainable agriculture" in the context of this purpose, implies that "agricultural systems throughout the world should become more productive and less wasteful". This requires "boosting yields on existing agricultural lands, including restoration of degraded lands, through sustainable agricultural practices would...", as well as "wise management of scarce water through improved irrigation and storage technologies..." (SDGs, 2019). At the moment the number of scientists and experts linking solutions to precision farming is constantly increasing.

A. Ross defines precision farming to be a combination of big data and agrochemical science. This is what takes agronomic sector from industrial epoch into digital epoch. (Ross, 2016). The concept's implementation involves collecting and analyzing large portions of data entering in a real-time mode and taking certain situational agrochemical measures using precise tools. 
"Precision farming" is a popular subject in scientific community. Research conducted by Romanian scientists states that "more than 5000 scientific papers have dealt with this topic over the past 25 years", interest towards the subject is subsequently growing. (Radulescuu et al, 2019). A number of publications cover separate technical aspects regarding various precision farming procedures organization. Researches on potential and implementation results of precision agricultural technologies (PATs) exists amongst those. Thus, Iranian researchers have analyzed factors influencing technology's promotion. They note farmer's positive attitude towards PATs to have an important part in accelerating its promotion. It's necessary to boost information flow, raise awareness of such technologies, and encourage farmers to implement them (Far et al, 2018). Furthermore, PATs adoption depends on computerization and farmers' investment opportunities. At this point those are still expensive technologies not available to all farming households within developed European countries. Also "...most of the farmers already using this technology face many difficulties in managing such a large amount of data collected by PATs and in using technologies efficiently." (Bucci et al, 2019). Application of innovative technologies to agricultural sector depends on institutional support and development of efficient decision tools (Mcconnell, 2019). The German Smart-AKIS hub's experts point out that most barriers to adoption smart farming technologies are linked to technologies' and infrastructures' deficits and "innovation targeted communication between farmers and technology developers or providers is not well developed" (Knierim et al, 2019).

Therefore, without a doubt, precision farming concept is gaining momentum and is accepted globally as a way to achieve sustainable agriculture development. Precision farming systems are yet imperfect, in need to evolve and have to become comprehensible, available to all farm households regardless of its size or location. However, lacking proper institutional and infrastructural support hinders the PATs dissemination process. Establishing such support given certain regional conditions, in our opinion, can be achieved on the basis of smart specialization approach, which implies building bridges between businesses, science, education, authority, as well as developing appropriate innovative ecosystems.

\section{Agrochemical ecosystem's development based on digital partnership in Luhansk region}

According to experts "by 2022, over $60 \%$ of global GDP will be digitized. An estimated $70 \%$ of new value created in the economy over the next decade will be based on digitally enabled platforms" (World Economic Forum, 2020). Nowadays digital technologies enter every field of economics and create an enabling environment for their integration. A modern example of such process is developing digital partnership between members of agrochemical value chain based on precision farming concept.

The study has revealed that Luhansk region has real resource capabilities for establishing this kind of partnership and further developing an "agricultural sector - chemical production" ecosystem as a regional smart domain. Ecosystem's model has to include three essential sectors: business, science, education (Figure 4). Its success depends on efficient communications between the leading stakeholders, which implies transfer 
knowledge, technologies and experience, developing a joint vision on evolution opportunities of existing or new productions, as well as focusing resources on agreedupon priorities.

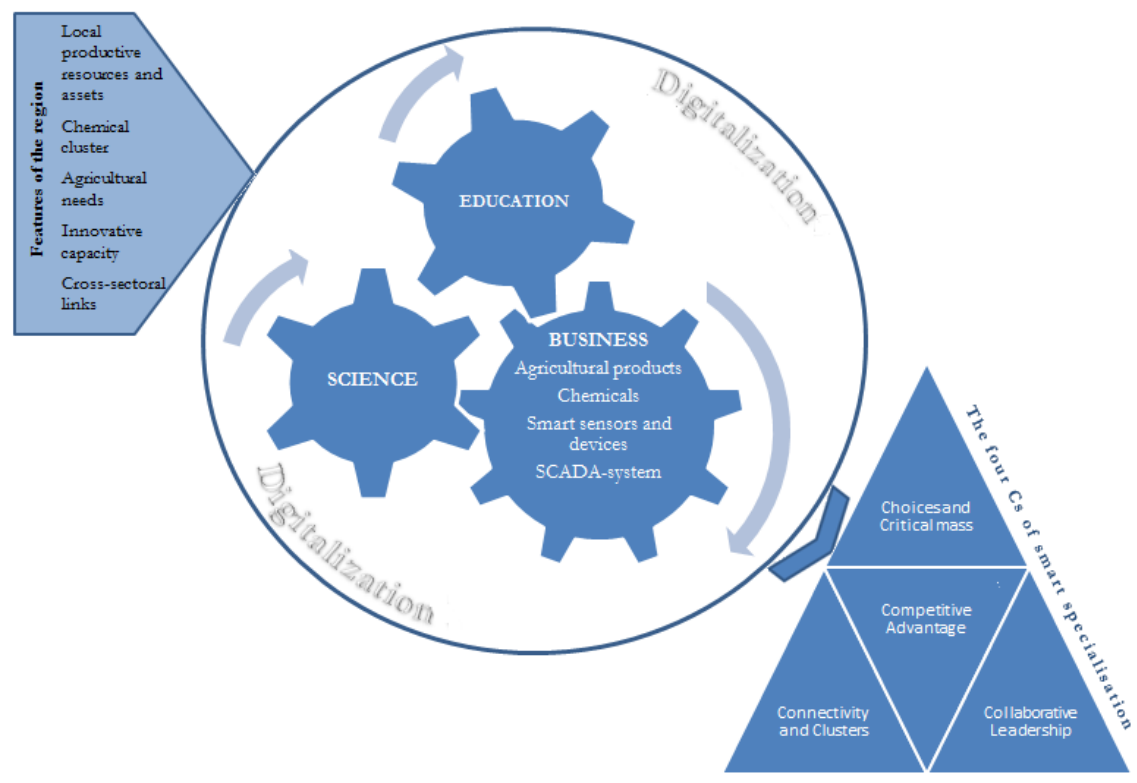

Figure 4. Agrochemical ecosystem model based on digital partnership

Each member of agrochemical ecosystem executes specified functions. Education is granted mostly by local universities - Volodymyr Dahl East Ukrainian National University, Luhansk National Agrarian University. Their involvement covers two sections of ecosystem - science and education. These particular members act as providers of research, test equipment, IT support on digital partnership, are training professionals. Business sector, conducting production and rendering services, partnered with university can execute joint R\&D and train professionals under dualistic education. The IT business has a significant role in enabling digital partnership by developing software, data mining and processing platforms, securing virtual environment and storing data. Farmers and other agricultural producers are consumers of ecosystem's innovative developments.

Cooperation benefits all the members. Farmers can expect increasing yields, resourcesaving, improved product quality, risk mitigation. Producers will receive guaranteed orders (chemicals, IT-products, special equipment, engineering services), improved product and scientific-technical quality, increased profitability. Universities will receive extra funding, research base evolution, enabling implementation of R\&D results into educational process.

Suggested ecosystem is bound to give positive externalities, particularly improve livelihoods and region's competitiveness. The population gets quality products, improved environment, as well as appropriate conditions for natural resource management and 
evolution of regional innovation systems.

We point out that revitalizing cooperation within agrochemical ecosystem based on digital partnership and promoting precision farming concept fully corresponds to four principles of economic transformation ("The four Cs") according to recommendations on specialization smart strategy development (Foray, 2012):

Choices and Critical mass: limited number of resources and priorities on the basis of region's own strengths.

Competitive Advantage: adapt innovative potential to business needs through an entrepreneurial discovery.

Connectivity and Clusters: develop clusters and provide platforms for cross-sector links internally in the region and externally.

Collaborative Leadership: provide efficient innovation systems based on public-private partnership.

The considered model contains a logical construct displaying the image of the desired future - that is, strategic vision on region's smart specialization results and agrochemical ecosystem's activity. Model's practical implementation is hampered by a number of problems: limited both information outreach and engagement of new regional actors into smart specialization; new activities and innovative projects experience difficulty in obtaining a critical mass; poor communication between entrepreneurial, educational, scientific, investment and financial structures of the region, lack of institutional cooperation tools, which interferes with transparency and inclusiveness of smart processes, constraining entrepreneurial discovery process, as well as evolution of region's innovative potential on smart basis.

To eliminate the problem mentioned above at the current level of region's innovation strategy development it's reasonable to create a coordination mechanism and web-space as scientific and technological platform being an institutional tool meant for managing region's smart specialization processes.

This mechanism enables organization of an effective communication between stakeholders, formation of local innovative ecosystems within smart specialization sectors, agree-upon strategic research and innovation programs, mobilize resources for smart-priorities implementation, ensures activity's inclusiveness, availability and regularity.

We consider those propositions to be the project idea's foundation for the Action Plan implementing the Luhansk Region Development Strategy until 2027. Importance and advantages of that idea are conditioned by the following criteria: it corresponds with core goals of the Strategy; influences the entire region; economically, socially, environmentally orientated; has high chances to be executed.

\section{Conclusion}

The crisis of post-conflict territories exists due to a combination of systemic and situational aspects. Ensuring region's sustainable development needs tools mobilizing inner resources and incorporating those into strategic planning to achieve the ultimate goal. The research grounds the smart specialization approach being one of the appropriate tools. 
Currently Luhansk region and the entire Ukraine undergo ruralization. However, low productivity of agricultural sector requires implementation of new technological solutions to intensify it.

On the other hand, this territory is old industries region. Chemical production is one of region's traditional industry sectors that preserved a major part of its manufacturing, scientific, educational and innovative potentials. We believe that establishing an agrochemical ecosystem based on digital partnership must become the smart priority for region's development. The agrochemical ecosystem model suggested contributes to modernization of interrelationships between manufacturers, science, education, authority and to consolidation of their efforts towards launching industry-specific transformations. That will enable to embrace yet hidden potential of cross-sectoral synergy, to find new leverage for economic recovery and ensure region's sustainable development.

\section{References}

Amosha, O. I., Shevtsova, H. Z., \& Shvets, N. V. (2019). Prerequisites for smart specialization of DonetskPrydniprovsky macro-region based on chemical production development. Economy of Industrry, 3 (87), 5-33. doi: doi.org/10.15407/econindustry2019.03.005.

Bucci, G., Bentivoglio, D., Finco, A., \& Belletti, M. (2019). Exploring the impact of innovation adoption in agriculture: how and where Precision Agriculture Technologies can be suitable for the Italian farm system? IOP Conf. Ser.: Earth Environ. Sci. 275 012004. doi: 10.1088/1755-1315/275/1/012004.

Detterbeck, K. (2017). Based on existing EDP Analyses and Regions'Experiences. Framework Document. Beyond EDP Interreg Europe project. Retrieved from: https://s3platform.jrc.ec.europa.eu/documents /20182/196760/Framework+Document/cb400189-e219-4b01-9f80-1b91ef0cd4e9.

Far, S.T., \& Rezaei-Moghaddam K. (2018). Impacts of the precision agricultural technologies in Iran: An analysis experts' perception \& their determinants. Information Processing in Agriculture, Vol. 5, Issue 1, 173-184. doi: 10.1016/j.inpa.2017.09.001.

Foray, D. (2012). Guide to Research and Innovation Strategies for Smart Specialisation (RIS 3). Joint Research Center. Retrieved from https://s3platform.jrc.ec.europa.eu/documents/20182/84453/RIS3+Guide.pdf /fceb8c58-73a9-4863-8107-752aef77e7b4.

Foray, D. (2015). Smart specialisation: Opportunities and challenges for regional innovation policy. London and New York: Routledge.

Knierim, A., Kernecker, M., Erdle, K., Kraus, T., Borges, F., \& Angelika, Wurbs. (2019). Smart farming technology innovations - Insights and reflections from the German Smart-AKIS hub. NJAS Wageningen Journal of Life Sciences, 90-91. doi: 100314. 10.1016/j.njas.2019.100314.

Mcconnell, M. (2019). Bridging the gap between conservation delivery and economics with precision agriculture. Wildlife Society Bulletin, 43(3), 391-397. doi: 10.1002/wsb.995.

OECD. (2013). Innovation-driven Growth in Regions: The Role of Smart Specialisation. Retrieved from http://www.oecd.org/sti/inno/smart-specialisation.pdf.

Panić, M. (2009). Post-conflict countries: aid effectiveness and permanent peace. Cambridge: University of Cambridge. Retrieved from http: http://citeseerx.ist.psu.edu/viewdoc/download? doi=10.1.1.366.4308\&rep= rep1\&type $=$ pdf.

President of Ukraine. (2019). President approved The Sustainable Development Goals of Ukraine until 2030. Retrieved from https://www.president.gov.ua/documents/7222019-29825.

Radulescuu, C.-V., Popescu, M.-L., Oancea Negescu, M. D., \& Bodislav, D. A. (2019). Digital Technologies Applied in Agriculture for Sustainable Development. European Journal of Sustainable Development, 8(5), 75. doi: 10.14207/ejsd.2019.v8n5p75.

Ross A. (2016). The industries of the future. Simon \& Schuster, UK Ltd.

SDGs online platform (2019). SDG 2. Retrieved from: https://sustainabledevelopment.un.org/topics $\angle$ foodagriculture. 
Semenenko, I., Halhash, R., \& Sieriebriak K. (2019). Sustainable development of regions in Ukraine: before and after the beginning of the conflict. Equilibrium. Quarterly Journal of Economics and Economic Policy, 14 (2), 317-339. doi: 10.24136/eq.2019.015.

Smart Specialisation Platform. (2016) Smart Stories, Implementing Smart Specialisation across Europe. Retrieved from: https://s3platform.jrc.ec.europa.eu/smart-stories.

Verkhovna Rada Ukrainy. (2015). Stratehiya staloho rozvytku "Ukrayina - 2020". Retrieved from http://zakon3.rada.gov.ua/laws/show/5/2015.

Wiatrak, A.P. (2018). Regional Smart Specialisations In Agribusiness. Humanities and Social Sciences, vol. XXIII, 25 (1/2018), p. 193-203. Retrieved from https://www.academia.edu/37140647/Regional smart specialisations in agribusiness Regionalne inteligentne specjalizacje $\mathrm{w}$ agrobiznesie ?auto $=$ down $\underline{\text { load }}$

World Economic Forum. (2020). Developing new economic and business models that are digitally driven, creating sustainable value for an inclusive economy. Retrieved from https://www.weforum.org/platforms/shaping-the-futureof-digital-economy-and-new-value-creation. 